
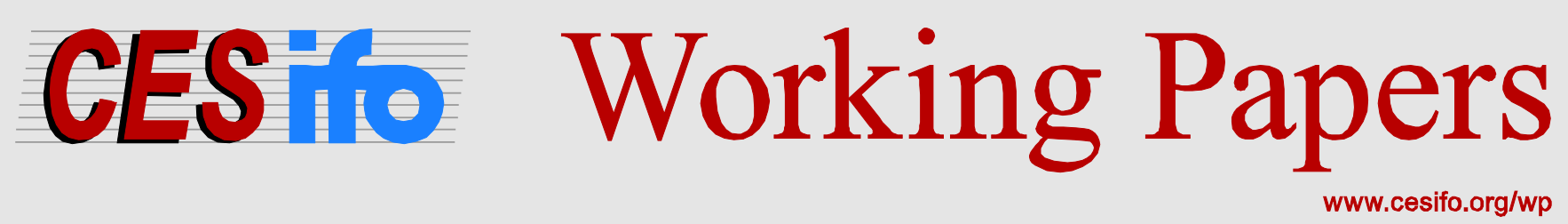

\title{
Pro-Cyclical Petroleum Investments and Cost Overruns in Norway
}

\author{
Roy Endré Dahl \\ Sindre Lorentzen \\ Atle Oglend \\ Petter Osmundsen
}

CESIFO WORKING PAPER NO. 6086

CATEGORY 13: BEHAVIOURAL ECONOMICS

SEPTEMBER 2016

An electronic version of the paper may be downloaded

- from the SSRN website: Www.SSRN.com

- from the RePEc website: Www.RePEc.org

- from the CESifo website: www.CESifo-group.org/wp 


\title{
Pro-Cyclical Petroleum Investments and Cost Overruns in Norway
}

\begin{abstract}
Development projects in the oil industry often have cost overruns. Through analysis of data from Norwegian development projects in the petroleum industry, this paper investigates the common effect of business cycle developments on cost overruns. Lack of capacity and expertise in a tight supplier market yield cost inflation and difficulties in managing projects. Unlike previous analyses of cost overruns, we analyse projects over a long time period to capture the cyclical effects. We document a statistically significant positive relationship between oil price developments and cost overruns, with shocks or surprises to the oil price during the project implementation having a larger impact on cost overruns than the oil price level itself. Cost overrun ultimately leads to reduced competitiveness for the industry, and we discuss consequences and policy implications for business and society of these cost overruns.
\end{abstract}

JEL-Codes: D220, D240, G310.

Keywords: cost overruns, petroleum projects, business cycle, oil price.

\author{
Roy Endré Dahl \\ University of Stavanger \\ Norway-4036 Stavanger \\ roy.e.dahl@uis.no \\ Atle Oglend* \\ Department of Industrial Economics \& \\ Risk Management / University of Stavanger \\ Norway - 4036 Stavanger \\ atle.oglend@uis.no
}

\author{
Sindre Lorentzen \\ University of Stavanger \\ Norway-4036 Stavanger \\ sindre.lorentzen@uis.no \\ Petter Osmundsen \\ University of Stavanger \\ Norway - 4036 Stavanger \\ petter.osmundsen@uis.no
}

*corresponding author

Thanks are due to a number of specialists in petroleum-related government agencies, the oil industry and the supplies sector for useful suggestions and comments. Thanks to the Research Council of Norway (Petrosam 2) for funding. 


\section{Introduction}

This paper analyses cost overruns on petroleum projects in Norway related to realized and expected capital expenditure (capex). Little quantitative research exist on cost overruns in petroleum projects, and this paper is one attempt to improve upon this. For Norway, there are two reports on cost overruns on the Norwegian continental shelf (NCS). The first is a report written on behalf of the Norwegian Petroleum Directorate (2013) that considers 5 megaprojects on the NCS. The findings in this report were compared to NOU (1999), a similar report produced by the Investment Committee in 1998. Although there are 15 years between the two reports, the conclusions are similar. Fist, cost overruns are considerable in all projects considered. Across the 16 projects considered in the reports, an average cost overrun of $50.63 \%$ was identified. Second, cost overruns are often identified in early phases of a project. Third, underestimating uncertainty and unrealistic ambitions create too optimistic estimates for project cost and progress. This factor together with insufficient time for pre-engineering is the main reasons for the cost overruns experienced according to the two reports.

Unrealistic ambitions and too optimistic estimates are likely correlated with the current business climate. A failure to incorporate the total cost effect of aggregate industry demand for services related to projects is likely to lead to cost overruns when making individual project decisions and projections. To take drilling as an example, which may represent up to $50 \%$ of the investments in a petroleum development project (Osmundsen et al. (2010)), no oil companies foresaw the tripling (312 \% between 2000 and 2013) of rig rates at the Norwegian shelf, see figure 10 below, combined with a large reduction in drilling productivity. Osmundsen et al. (2012) show that an increase in oil price leads to a decrease in drilling speed and Osmundsen et al. (2015) demonstrate that a higher oil price causes higher rig rates. The combined effect of increasing rig rates and decreasing drilling speed was an explosive increase in drilling cost. In the current downturn in the industry we see a dramatic fall in rig rates and receive reports of a large increase in drilling speed. The facts suggest that drilling cost are responsive to the business cycle. This is partly due to scarcity of certified rigs in boom periods. Partly one may argue that it is qualified personnel that represent the underlying scarce factor. Rigs are supplied with personnel, and wages are included in the rig rate. Other oil service companies and the oil companies also struggle to find competent personnel when all companies are recruiting at the same time.

In this paper, we study the effect of the business cycle on the accuracy of project cost estimates, using data from the Norwegian Continental Shelf (NCS). Our first hypothesis is that the business cycle of the 
oil industry is likely to affect the extent of cost overruns. There are several potential indicators for the business cycle to use in such an analysis. We make a distinction between global and local indicators, where the global indicators affect the entire oil industry while local indicators are particularly important for the Norwegian shelf. We use the oil price as an indicator for the current global industry business cycle and as an indicator for future income expectations. ${ }^{2}$ Since cost overruns can be perceived to be associated with an unexpected oil price increase, we construct an oil price surprise variable, defined as the relative difference between the current oil price and the oil price at the time of the project sanctioning. This is used as our global business cycle explanatory factor. As explanatory factors for the local business cycle, we apply employment surprise, investment surprise, wage surprise and surprise in rig rates in new contracts on the NCS. Investment and employment refer to the overall activity in the Norwegian petroleum sector, where a high level typically is associated with lower average input quality and bottlenecks at various parts of the value chain. This brings us to our second hypothesis, whether cost overruns are more responsive to global or local business cycle indicators. After the last large incidence of cost overruns in the 1990s, oil companies reported to the Investment commission (NOU 1999:11) that lack of competent personnel and insufficient internal project management resources were their primary concern. Thus, our second hypothesis is that local business cycle parameters are most important in explaining cost overruns.

Our analysis provide useful input to cost estimation. The Norwegian government report on cost overruns of projects in the North Sea (NOU 1999:11) concluded that there was a $26 \%$ increase in development costs from project sanction (PDO, Plan for Development and Operation) to last CCE (Capital Cost Estimate) for the 11 oil field projects investigated. Many reasons like unclear project assumptions in early phase, optimistic interpolation of previous project assumptions, too optimistic estimates, and underestimation of uncertainty were given as reasons for overruns.

Emhjellen et al. (2002) highlight the possibility that the cost overruns can also be related to an error in the estimation and reporting of capex. Usually the capex is given by a single cost figure, with some indication of its probability distribution. The oil companies report, and are required to do so by government authorities, the estimated 50/50 (median) cost estimate instead of the estimated expected value cost estimate. Emhjellen et al. demonstrate how the practice of using a 50/50 (median) capex estimate for the 11 projects when the cost uncertainty distributions are asymmetric, may explain at least part of the "overruns". Hence, the authors advocate changing the practice of using median cost estimates in favor of expected value cost estimates for project management and decision

\footnotetext{
${ }^{2}$ The price of oil is difficult to forecast over longer periods (Hamilton, 2009), and due to long lead-time from investment commitment to production start, uncertainty is substantial for any project in the petroleum industry.
} 
purposes. We augment their findings by demonstrating that an important and often underestimated cost driver is the effect of the business cycle. Lack of capacity and expertise in a tight supplier market yield cost inflation and difficulties in managing projects. Unlike previous analyses of cost overruns, we have analysed projects over a long time period so that we capture cyclical effects.

Previous empirical research on investment patterns in the Norwegian petroleum sector is related to exploration, see Mohn and Osmundsen $(2008,2011)$. We look at the major component of petroleum investment - development projects. Fluctuations in development investment in response to changes in oil and gas prices are considerably smaller than for exploration spending - partly because longer lead times and low success rates make exploration more risky and thus more price sensitive, and partly because exploration unlike development can be reduced at short notice.

Flyvbjerg et al. (2003) study cost overruns in public megaprojects, and find that optimism bias and strategic misrepresentation lead to poor decision basis. Consequently, overoptimistic projects are chosen due to their underestimated costs and overestimated revenues. Moreover, since a megaproject is big by definition, it is difficult to cancel after it has been initiated due to already heavy investments. As such, Flyvbjerg et al. find that even substantial cost overruns are ignored in order to complete the project. Some of these characteristics of public megaprojects may also be true for megaprojects in the petroleum industry, and short-term and long-term considerations need careful balancing in order to ensure beneficial development and to avoid pro-cyclicality.

Policy makers in oil exporting countries need to consider the incentives for successful implementation of petroleum projects. This is crucial to the industry where marginal cost is expected to increase over time due to complexity of unconventional oil, and several recent papers (van Moerkerk and CrijnsGraus, 2016; Speirs et al., 2015; Bentley and Bentley, 2015) argue that oil supply will be tight in the future. Owen et al. (2010) review the status of conventional oil reserves and suggest that commercially exploited oil is limited and will decline. This is also the conclusion in Benes et al. (2012) whom address the limits to geology as easy and conventional oil reserves are reduced, and the possibilities of technological developments to reduce cost from unconventional and complex oil reserves. Oil supply involves all countries globally and energy security is discussed in several papers (Helm, 2002; Yergin, 2006; Stirling, 2010, Yang et al., 2014). North America, Europe and Asia-Pacific have been dependent on oil imports, while the Middle East has provided supply of oil through its abundance of oil resources. To increase future energy security, the world relies on projects with lower cost overruns than typically experienced today. First, this will create profitability for the exporting countries. In addition, and perhaps more importantly, for importing countries profitable projects will provide oil at a lower cost. For the petroleum industry, cost overruns lead to reduced profitability, and ultimately to reduced 
competitiveness. Poorly implemented projects require higher capital reserves and consequently increase the cost of capital.

According to Merrow (2011, 2012), the petroleum industry is particularly poor at delivering at budget and on time. The success rate in the petroleum industry is only 25\% and Merrow (2012) argues that one key reason is the petroleum industry's high turnover in project leadership. Moreover, Mishra (2014) at IPA, indicates that projects undertaken on the Norwegian continental shelf (NCS) perform worse than comparable projects undertaken in the Gulf of Mexico (GoM). Their report shows that Norwegian projects less frequently use repeated designs, which are standardized design used in several projects. Other previous studies on NCS relates to drilling and efficiency (see, for example, Mohn and Osmundsen, 2008; 2011 and Mohn 2008).

While several papers address the importance of technological and governmental regulation of oil and gas production and extraction, our paper will provide insights on the managerial challenges in securing a stable oil and gas supply as addressed in Andriosopoulos et al. (2016). Cost overruns are inefficient and policy development and monitoring is equally important as forecasting and risk management for a company developing oil and gas fields. Moreover, uncertainties about the closing cost adds capital cost to the operating company, thus limiting the company from undertaking other profitable projects. Finally, with increasing environmental demands and the remoteness of reserves, the complexity of future projects is likely to increase, emphasizing the importance of policy and incentives for decisionmakers to generate efficient projects.

We will investigate projects on the Norwegian continental shelf (NCS) going back to 2000, and compare cost overruns to our proxy for the business cycle. We use yearly data from Ministry of Petroleum and Energy, provided by license holders/operators on NCS that are required to provide a yearly report on actual cost and cost estimates for development projects. Our main finding is that cost overruns are higher, in relative terms, when oil prices and other proxies for economic activity increase during project implementation. As such, the industry may be pro-cyclical. Furthermore, economic activity variables of a local origin, especially sector employment on the NCS, appears to yield a higher explanatory power than global variables such as the oil price. Although we are able to identify the oil price as common factors for cost overruns, there is significant heterogeneity in cost overruns. By evaluating the majority of petroleum projects on the Norwegian continental shelf, we assess projects that typically involve complex technological solutions for offshore oil platforms. As consumers and industry will continue to rely on fossil fuel for energy, project complexity will increase since oil and gas fields are becoming more remote and unconventional. Hosseini and Shakouri (2016) use oil price scenarios to simulate future oil supply, and conclude that between $20 \%$ and $25 \%$ of future oil will come from unconventional oil 
production. The results from our study will help provide insights on cost overruns related to business cycles for complex projects.

The paper is structured as follows. In section 2, we review petroleum activity on the Norwegian continental shelf and in section 3, we present project cost data provided by the Ministry of Petroleum and Energy from 2000 until 2013. In section 4, we consider key variables related to the petroleum industry and in section 5 we present the regression analysis. In section 6 , we provide a discussion of our results.

\section{The Norwegian continental shelf (NCS)}

There has been oil and gas drilling on the Norwegian Continental Shelf (NCS) since the early 1970s. Figure 1 shows yearly oil and gas production on the NCS. Oil and gas output from the NCS increased steadily until it peaked in 2004 at 264000 million standard m3 (Sm3) of oil equivalents (o.e.). Recent years have seen a reduction in output and in 2014 production was 219000 million Sm3 of o.e. This reduction has come from lower oil production, dropping from 181000 million Sm3 in both 2000 and 2001 to 88000 million Sm3 in 2014.

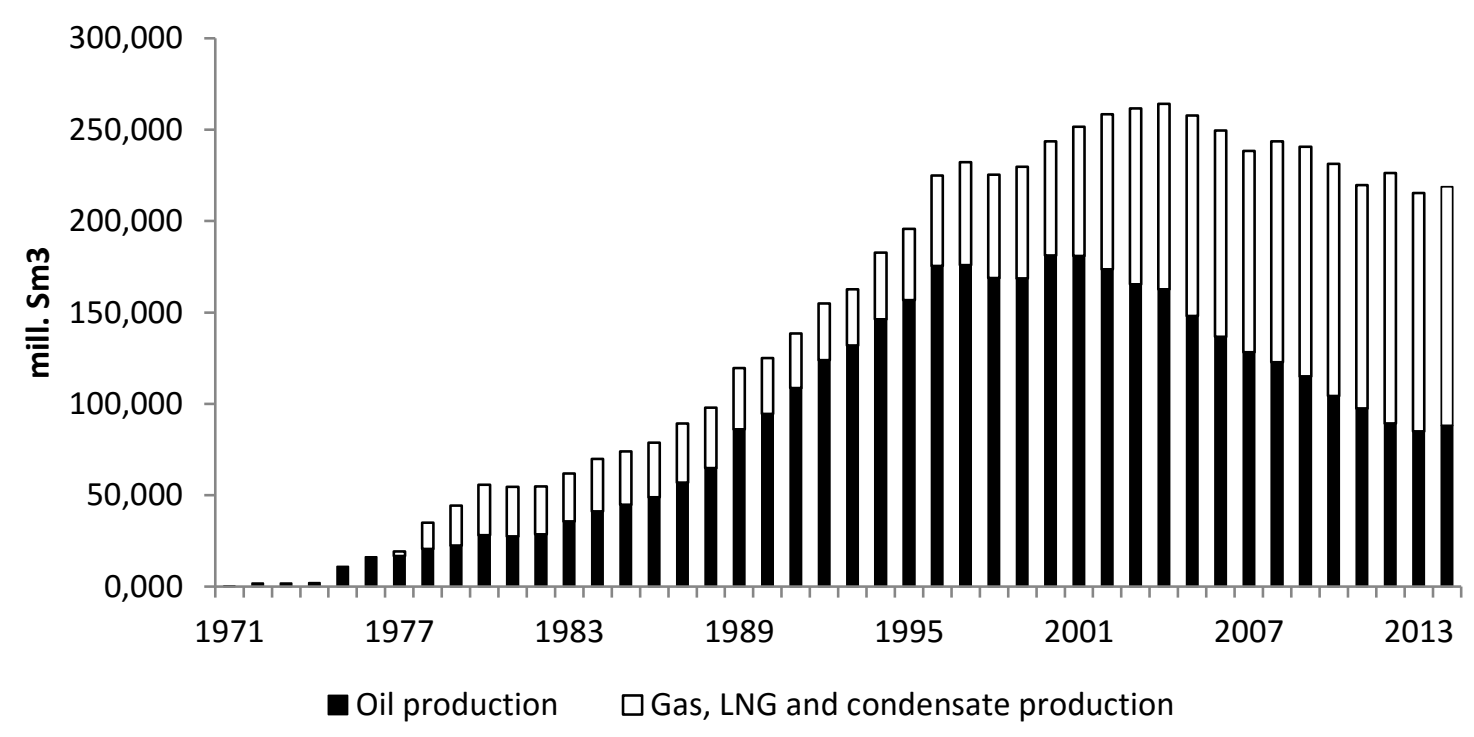

Figure 1. Yearly oil and gas production on NCS in mill. Sm3

Petroleum activity on the NCSs is important to the Norwegian economy, and petroleum related projects provide huge benefits to the Norwegian society. As oil production declined in the beginning of the 2000s, the Norwegian government added extra incentive for exploration investment with advanced tax deductions in 2005. This provided immediate tax deduction of exploration expenses and immediate repayment of negative tax positions, making it easier for smaller companies to take on exploration projects. As a result, exploration activity increased. Several new companies were 
established and many existing companies put up business in Norway to take advantage of the new tax regime in the search for new oil and gas fields. While the immediate effect was on exploration, and not on development projects, some of the new fields discovered are in our data set on development projects.

Figure 2 shows how increasing oil prices resulted in an increase in total investments on the NCS. While the total investments in 2000 was just above 50 billion NOK in 2014, the investments quadrupled to 214 billion NOK.

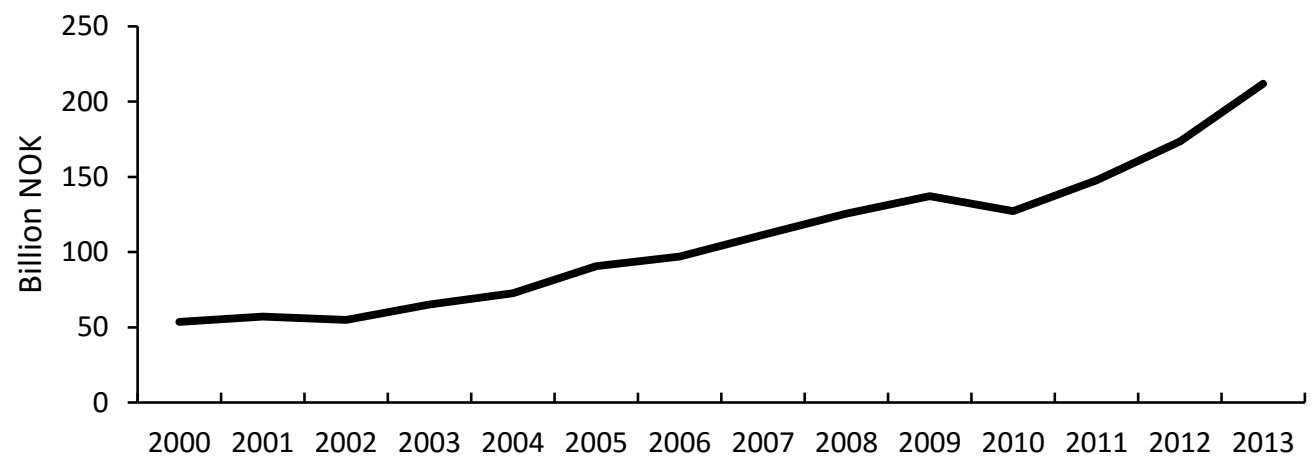

Figure 2. Total yearly investments on NCS in billion NOK

\section{Statistical analysis of Norwegian oil projects}

To analyze oil projects on the NCS we use data collected from the Norwegian Ministry of Oil and Energy based on approval of plans for development and operation (PDOs) and special permits for installation and operation (PIOs), pursuant to the Petroleum Act. ${ }^{3}$ In total, the study considers 80 projects during the interval 2000-2013. Typically, the projects have estimates over several years, allowing us to compare cost estimates over time, although a project will not cover the entire data period. Consequently, the number of projects active each year varies over the sample, starting with 8 projects in 2000 and ending with 27 projects in 2013 (see table 1). All cost estimates are inflation adjusted to year 2000 NOK values using the Norwegian index on inflation ${ }^{4}$. Although the majority of costs are paid in NOK, goods purchased in USD, EUR or other currencies will cause currency effects. Due to the increasing strength in the NOK for the period studied, this should have a positive effect on cost estimates, thus reducing cost overruns. The capex estimate in the paper is the official cost estimate

\footnotetext{
${ }^{3}$ http://www.npd.no/global/engelsk/5\%20-\%20rules\%20and\%20regulations/guidelines/pdo-pioguidelines 2010.pdf

${ }^{4}$ Consumer price index from Statistics Norway.
} 
the license has communicated to the authorities. When forming such cost estimates it is customary to add a percentage for unexpected costs, a so-called contingency. While this may vary from company to company, a typical range on a license basis is $20-30 \%$. So, the cost overruns measures are cost realizations above cost estimates including contingency.

Figure 3 shows that on average project size has been increasing throughout the sample period, from 6.5 MNOK to almost 20 MNOK in 2013. This increase can also be seen in the rising share of megaprojects in table 1 and figure 4; the cost estimates and actual cost are rising.

Table 1. Number and average cost of projects. Megaprojects >= 10000 MNOK

\begin{tabular}{ccccccccccccccc} 
& $\mathbf{2 0 0 0}$ & $\mathbf{2 0 0 1}$ & $\mathbf{2 0 0 2}$ & $\mathbf{2 0 0 3}$ & $\mathbf{2 0 0 4}$ & $\mathbf{2 0 0 5}$ & $\mathbf{2 0 0 6}$ & $\mathbf{2 0 0 7}$ & $\mathbf{2 0 0 8}$ & $\mathbf{2 0 0 9}$ & $\mathbf{2 0 1 0}$ & $\mathbf{2 0 1 1}$ & $\mathbf{2 0 1 2}$ & $\mathbf{2 0 1 3}$ \\
\hline \# megaprojects & 2 & 3 & 3 & 4 & 5 & 5 & 7 & 7 & 8 & 6 & 5 & 11 & 13 & 16 \\
\# other projects & 6 & 15 & 14 & 16 & 14 & 17 & 15 & 17 & 14 & 11 & 10 & 11 & 11 & 11 \\
\hline Total projects & $\mathbf{8}$ & $\mathbf{1 8}$ & $\mathbf{1 7}$ & $\mathbf{2 0}$ & $\mathbf{1 9}$ & $\mathbf{2 2}$ & $\mathbf{2 2}$ & $\mathbf{2 4}$ & $\mathbf{2 2}$ & $\mathbf{1 7}$ & $\mathbf{1 5}$ & $\mathbf{2 2}$ & $\mathbf{2 4}$ & $\mathbf{2 7}$ \\
$\begin{array}{c}\text { Average cost } \\
\text { (thousand MNOK) }\end{array}$ & 6.5 & 4.1 & 4.5 & 4.2 & 8.5 & 7.3 & 8.3 & 10.6 & 10.8 & 10.5 & 13.0 & 14.0 & 16.1 & 20.0 \\
\hline
\end{tabular}

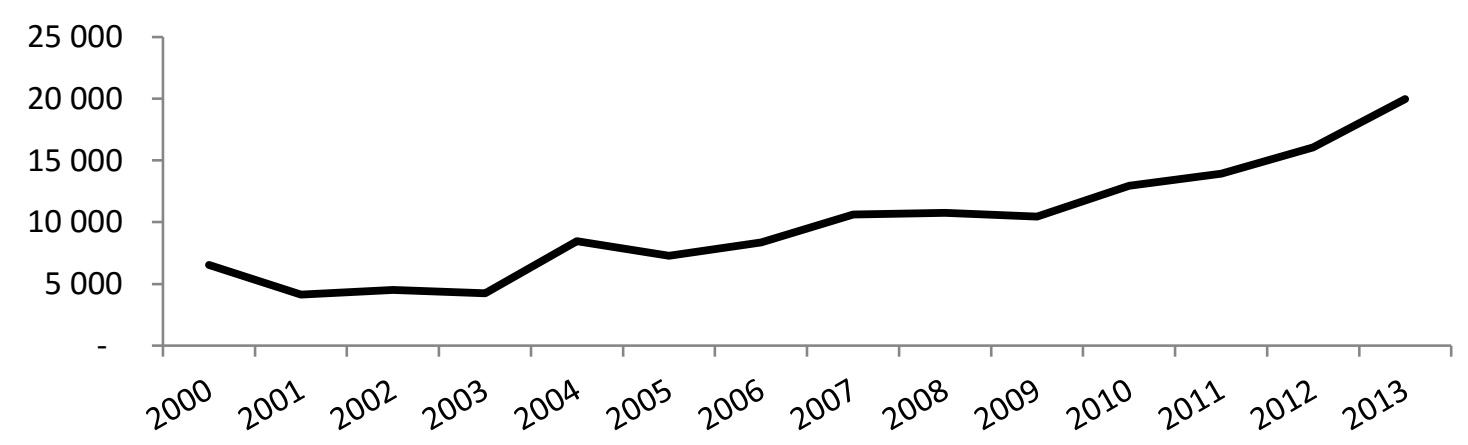

Figure 3. Average cost estimate in MNOK

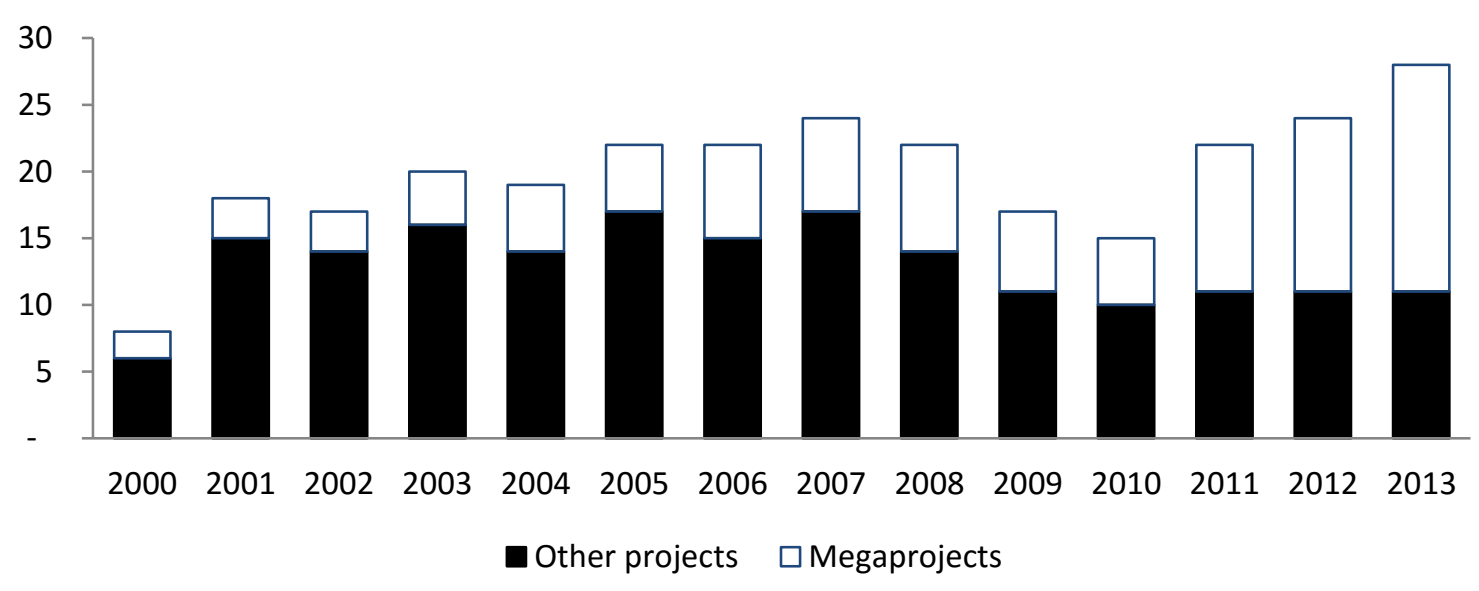

Figure 4. Number of projects per year. Megaprojects >= 10000 MNOK 
In figure 5 and figure 6 , we have tried to identify when the cost overrun is typically experienced for a project. It is evident from figure 5 that cost overruns are accumulated throughout the project lifetime. Moreover, figure 6 shows that the size of the cost overrun in percentage is increasing with the number of years since project start. While the cost overrun is on average $6 \%$ in year 1 , it increases to around $12 \%$ in both the $3^{\text {rd }}$ and $4^{\text {th }}$ year. From these figures we find that both the accumulated cost overrun and the yearly cost overrun increases with the age of the project, with projects lasting more than 4 years having the biggest cost overruns.

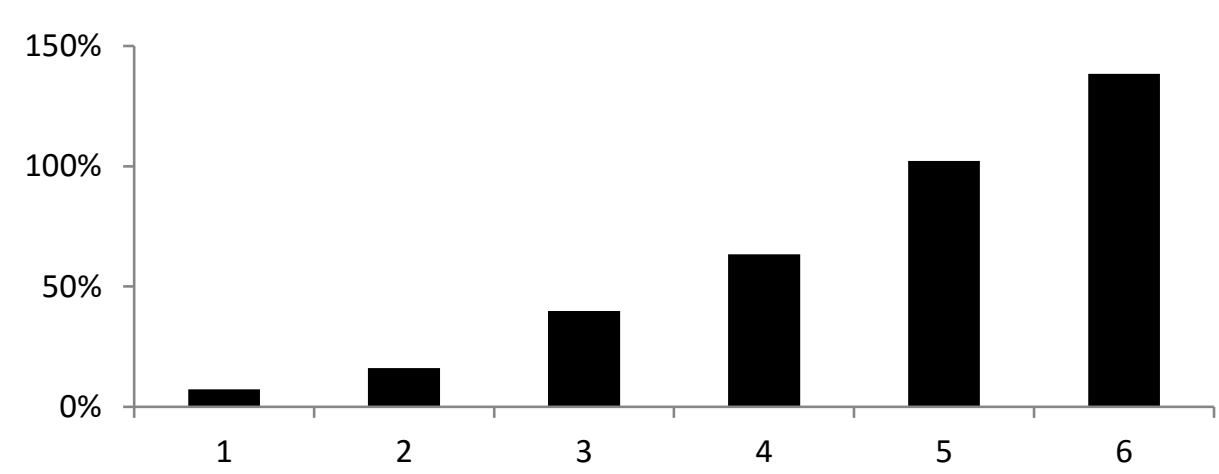

Figure 5. Total cost overrun in years after initial PUD-acceptance

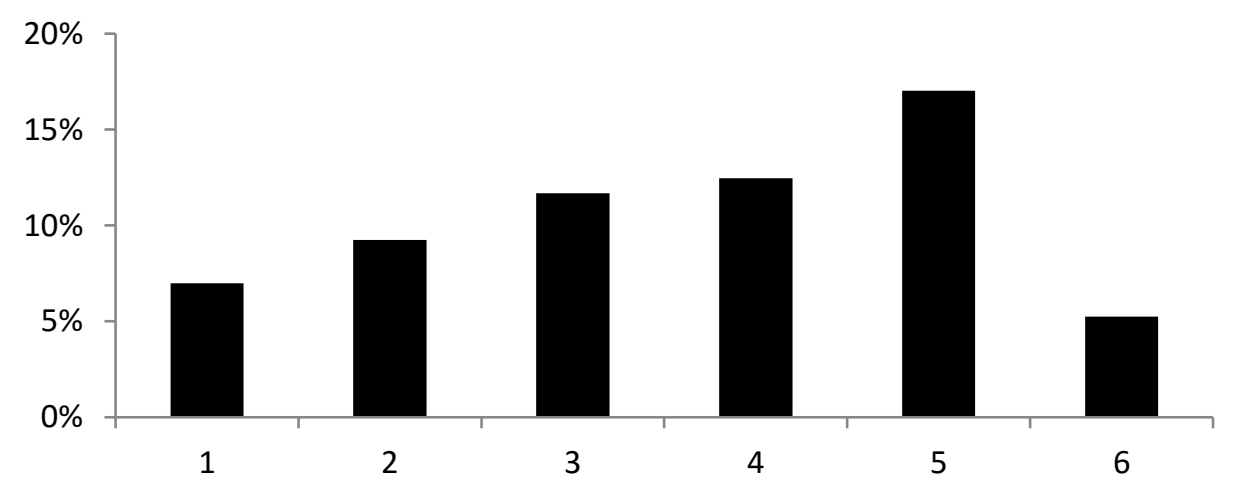

Figure 6. Yearly cost overrun years after initial PUD-acceptance 


\section{Empirical analysis on key variables}

For the empirical analysis of cost overruns we consider several factors related to the investment level found on the NCS. We focus on variables that are volatile and thus may generate surprises that may lead to cost overrun. Typically, the variables are related to the business cycle of the petroleum industry. Some of the variables are global, like the oil price, and others are local, like rig rates and wages. Since the Norwegian petroleum industry is part of a global industry one might think that the latter variables also are global. However, as demonstrated by the Rig Commission (2011), regulations imposed by Norwegian authorities and by agreements between oil companies and trade unions, the Norwegian rig and labor market is partly shielded from direct international competition and thus partially segmented. See table 2 and 3 for a list of all evaluated variables.

Table 2. List of economic activity variables

\begin{tabular}{llll}
\hline \multicolumn{1}{c}{ Variable } & \multicolumn{1}{c}{ Description } & $\begin{array}{c}\text { Level of } \\
\text { relevance }\end{array}$ & $\begin{array}{c}\text { Expected } \\
\text { relation }\end{array}$ \\
\hline Oil Price & $\begin{array}{l}\text { Price of brent crude oil (USD/bbl) on a yearly } \\
\text { frequency aggregated as the average monthly } \\
\text { price. }\end{array}$ & Global & $\uparrow$ \\
Gas price & $\begin{array}{l}\text { Price of (Henry Hub) natural gas (USD/Million } \\
\text { Btu) on a yearly frequency aggregated as the } \\
\text { average monthly price. }\end{array}$ & Global & $\uparrow$ \\
Employment & $\begin{array}{l}\text { Number of thousands workers employed in oil } \\
\text { and gas production in Norway. }\end{array}$ & Local \\
Investment & $\begin{array}{l}\text { Aggregate amount of bn NOK invested on the } \\
\text { oil and gas sector on the NCS. }\end{array}$ & Local \\
Rig rates & $\begin{array}{l}\text { Average rig rates for floaters, 1 000 USD per } \\
\text { day, on the Norwegian continental shelf. }\end{array}$ & Local & $\uparrow$ \\
Wages & $\begin{array}{l}\text { Average annual wages in 1 000 NOK for } \\
\text { employees related to Norwegian petroleum } \\
\text { activities }\end{array}$ & Local & $\uparrow$ \\
\hline
\end{tabular}

Note: This table shows the list of all evaluated economic activity variables. Variable name, description of variable, the variables level of influence and its expected relation to the cost overrun is presented. 
Table 3. List of surprise and control variables

\begin{tabular}{llll}
\hline \multicolumn{1}{c}{ Variable } & \multicolumn{1}{c}{ Description } & \multicolumn{1}{c}{$\begin{array}{c}\text { Level of } \\
\text { relevance }\end{array}$} & $\begin{array}{c}\text { Expected } \\
\text { relation }\end{array}$ \\
\hline Oil price surprise & $\begin{array}{l}\text { Relative difference between oil price in current } \\
\text { year and the year of the PDO. }\end{array}$ & Global /Project & $\uparrow$ \\
Gas price surprise & $\begin{array}{l}\text { Relative difference between gas price in } \\
\text { current year and the year of the PDO. }\end{array}$ & Global /Project & $\uparrow$ \\
Employment surprise & $\begin{array}{l}\text { Relative difference between number of } \\
\text { employees in the petroleum sector in Norway } \\
\text { for the current year and at the time of the PDO. }\end{array}$ & Local /Project & $\uparrow$ \\
Investment surprise & $\begin{array}{l}\text { Relative difference between aggregate } \\
\text { investment in the petroleum sector in Norway } \\
\text { for the current year and at the time of the PDO. }\end{array}$ & Local /Project & $\uparrow$ \\
Rig rate surprise & $\begin{array}{l}\text { Relative difference between rig rates in the } \\
\text { petroleum sector in Norway for the current } \\
\text { year and at the time of the PDO. }\end{array}$ & Local /Project \\
Relative difference between wages in the \\
Wage surprise
\end{tabular}

Note: This table shows the list of all evaluated surprise and control variables. Variable name, description of variable, the variables level of influence and its expected relation to the cost overrun is presented.

All data was tested for unit root. The Augmented Dickey Fuller (ADF) test and the Phillips-Perron test was used for the economic activity variables in table 2, while Fisher panel data unit root test by Maddala and Wu (1999) with both the augmented Dickey-Fuller and Phillips-Perron specification was used for the surprise variables in table 3 . Table $1 \mathrm{~A}$ and $2 \mathrm{~A}$ in the appendix shows the results of the unit root tests. The time series dimension is very low, and so the tests are likely to suffer reduced power. Full test results can be found in the appendix. All economic variables show evidence of unit root. This is not surprising, given the strong trending nature of these variables. The surprise and control variables show more mixed results, but still most tests fail to reject unit root. Inferring the order of integration of the data on such small sample is challenging. Our analysis will proceed under the caveat of unit roots in the data, and so spurious correlations cannot be confidently ruled out. However, the surprise variables are more likely from a theoretical point to be stationary, and so inference based on the surprise variables are likely more robust, and the chance of spurious correlation less likely. It is also 
possible that further information could be gained by including ratios of economic activity variables in explaining cost overruns. Cochrane (1994) for instance show that accounting for cointegration can improve forecasts of macro-economic variables. This is an interesting venue for future research, but we do not pursue the possibility for cointegration between economic activity variables in this paper as samples are considered too small to robustly infer credible long run relationships.

Figure 7 shows the price of oil (Brent) during the period studied (annual averages). It is evident that both have seen a steady increase throughout the sample period. From only 30 USD/bbl in 2000, the oil price reached 98 USD/bbl on average in 2013.

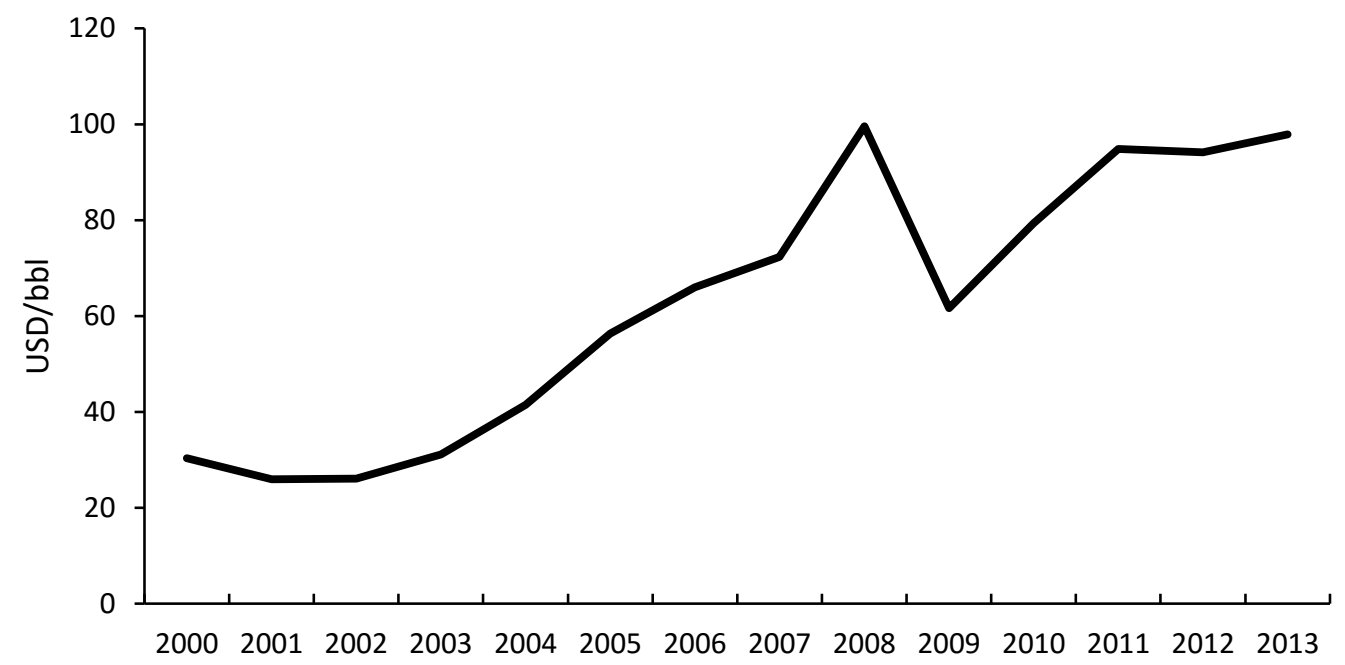

Figure 7. The price of oil (Brent), 2000-2013

Similar to figure 7, figure 8 shows the natural gas price development. Unlike the oil price, the gas price has not experience the same long lasting upward trend throughout the sample period.

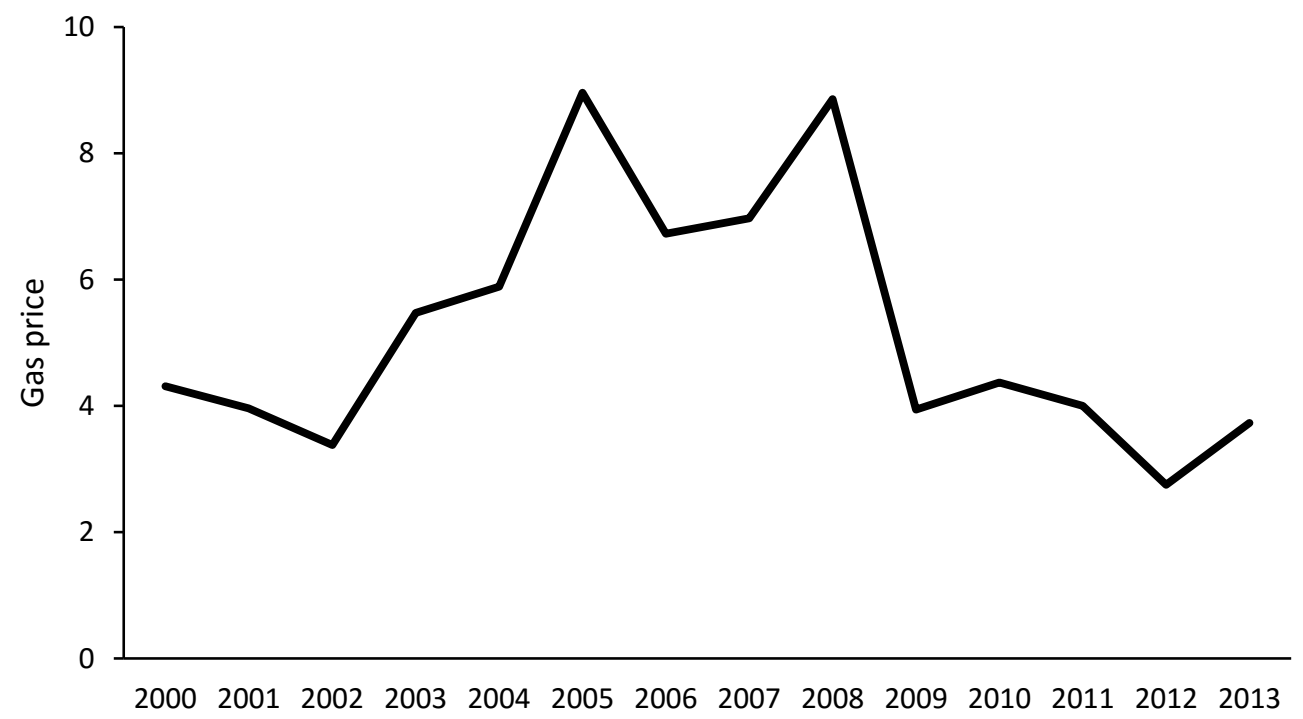

Figur 8. Gas price dollars per Million Btu, 2000-2013 
Figure 9 shows the development in the number of employees in the oil and gas sector on the NCS throughout the sample period. As discerned from the graph, employment has steadily increased.

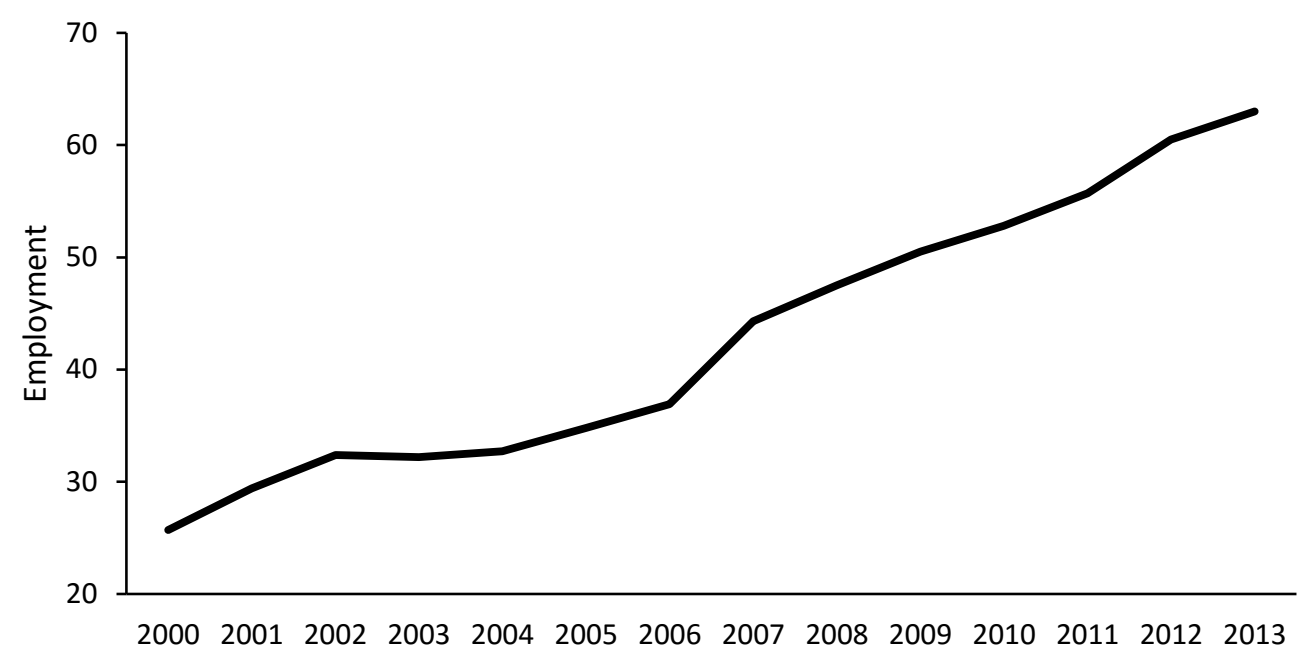

Figur 9. Employment on the NCS (numbers in thousands), 2000-2013

Figure 10 displays average rig rates for floaters, USD per day, on the Norwegian continental shelf. The correlation with the oil price is apparent, as price of rig rates has steadily increased throughout the period, only interrupted during the financial crisis.

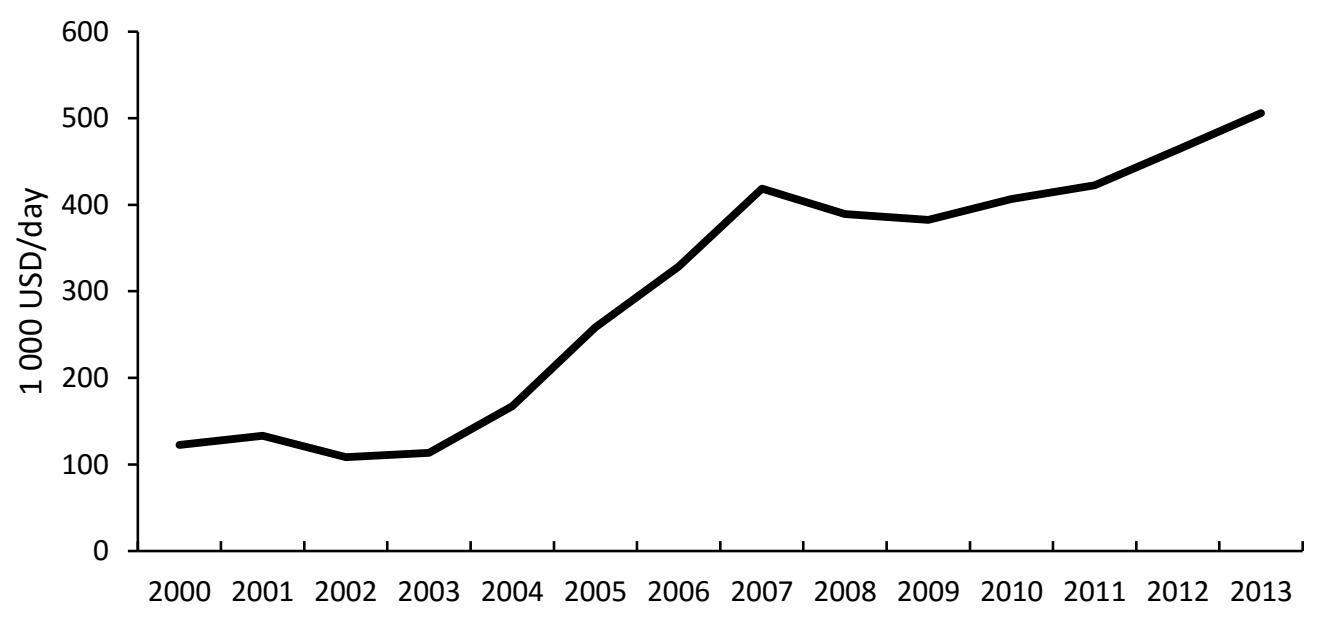

Figure 10. Average rig rates for floaters, 1000 USD per day, on the Norwegian continental shelf Another cost variable concerning the profitability of a petroleum project is wages. Figure 11 shows the average wage cost from 2000 to 2013. Wages have increased during the entire period, and on average the annual salary was more than 900000 NOK in 2013 compared to about 510000 NOK in 2000. In comparison, the average annual salary in Norway in general was 380000 NOK in 2013. 


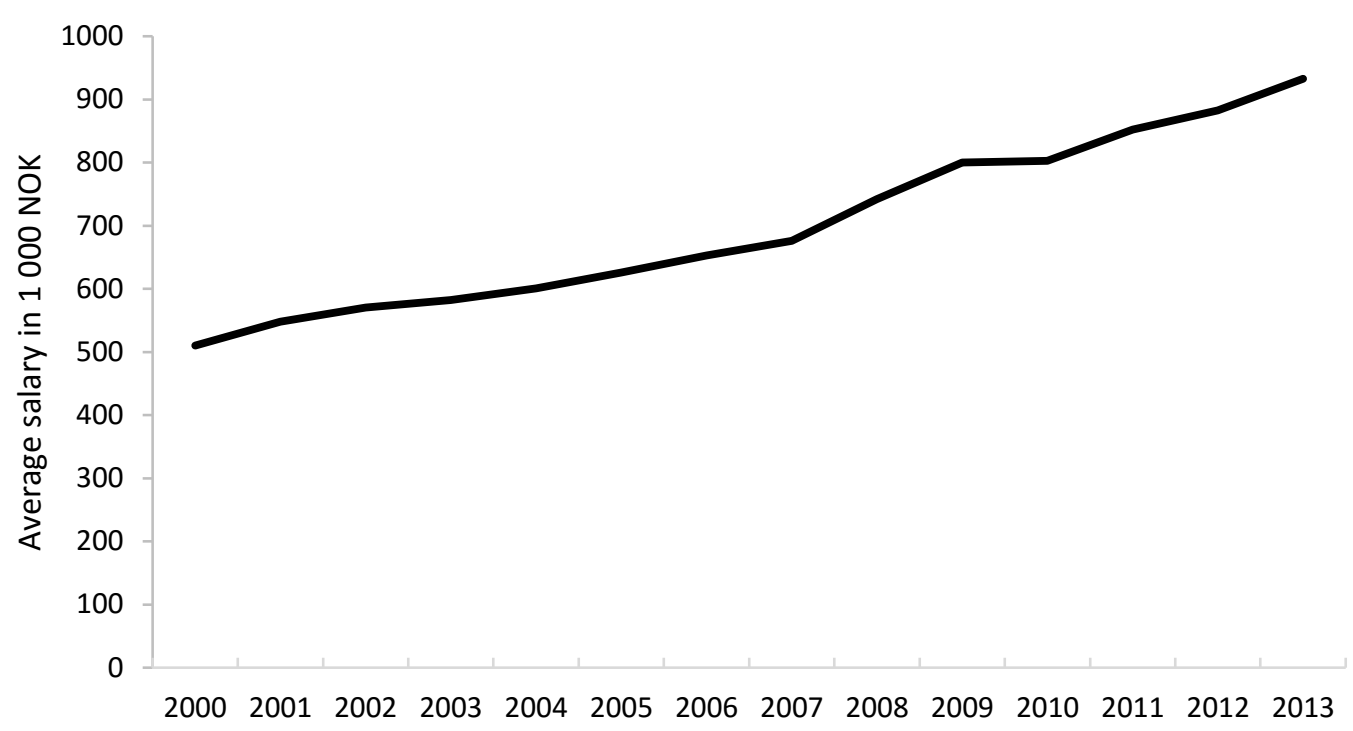

Figure 11. Average annual wages in 1000 NOK for employees related to Norwegian petroleum activities

Table 4 and figure 12 shows correlations between the oil price and key variables related to investment costs on the Norwegian continental shelf. The strong correlation illustrates the importance of cost increases related to the business cycle. With higher energy prices, projected revenues from projects increase, putting pressure on capacity and project development services in a tight supplier market. The strong correlation also highlights the difficulty in isolating effects of individual cost related variables on cost inflation, making it reasonable to aggregate these variables into a common business cycle factor. Since trends in oil prices can be considered exogenous to Norwegian petroleum activity, we represent this factor by the oil price and proceed to investigate their association with average project cost overruns.

Table 4. Correlations between key investment cost variables

\begin{tabular}{lccccc}
\hline & Oil price & Rig rates & Investments & Wages & Employees \\
\cline { 2 - 6 } Oil price & 1 & & & & \\
Rig rates & 0.950 & 1 & & & \\
Investments & 0.896 & 0.932 & 1 & & \\
Wages & 0.880 & 0.910 & 0.979 & 1 & \\
Employees & 0.900 & 0.932 & 0.970 & 0.995 & 1 \\
\hline
\end{tabular}

Note: Rig rates refer to average rig rates for floaters, USD per day, on the Norwegian continental shelf (source: RS Platou). Investments are total petroleum related investments on the Norwegian continental shelf (source: SSB). Wages are wages for employees related to Norwegian petroleum activities (source: SSB), and employees are number of employees related to Norwegian petroleum activities (source: SSB). 


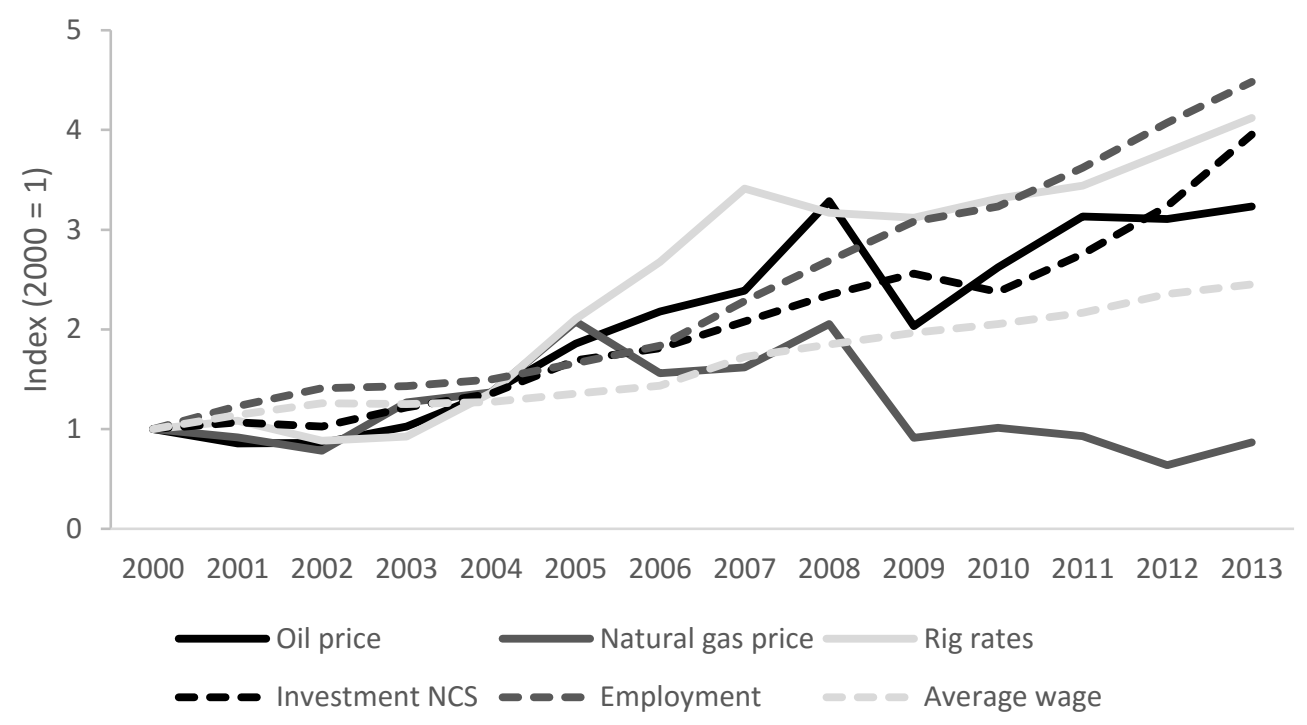

Figure 12. Key variables indexed to $2000=1$ from 2000 to 2013. Variables include oil price, natural gas price, rig rates, total yearly investment on NCS, employment related to the petroleum industry and average wages related to the petroleum industry

Based on the presented proxies for the economic activity (oil price, gas price, rig rates, investment, employment and wage) the surprise variables are constructed as the relative difference between the current value of the given variable and at the time of the PDO approval. Implicitly, it is assumed that oil and gas companies utilize a driftless random walk as their model of forecasting. Undoubtedly, the various firms have a heterogeneous approach forecasting variables of relevance. However, as the companies methodology is unknown, the most parsimonious approach is opted for, i.e. random walk.

Figure 13 shows the development in oil price surprise both over calendar and execution year (current duration of project). As observed in (a), there is a significant albeit economically weak upwards trend in the oil surprise over the sample period. Furthermore, as seen in (b) the development during project execution reveals a comparably stronger upwards trend. 
(a) Year

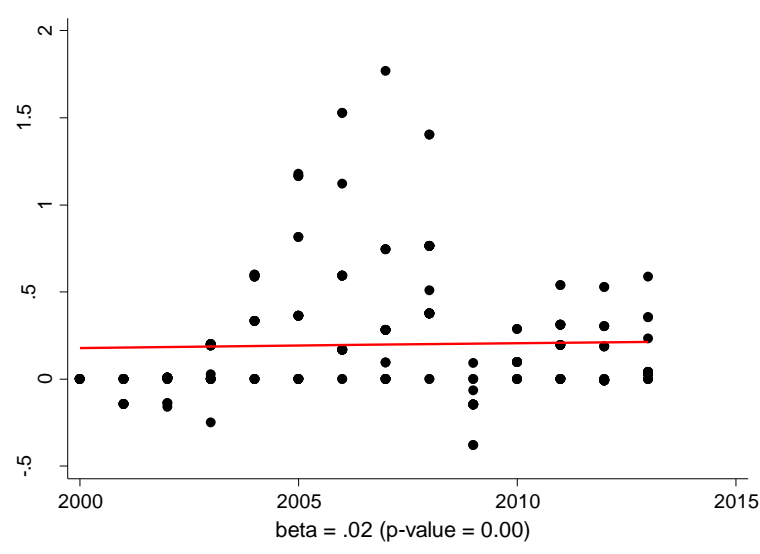

(b) Execution year

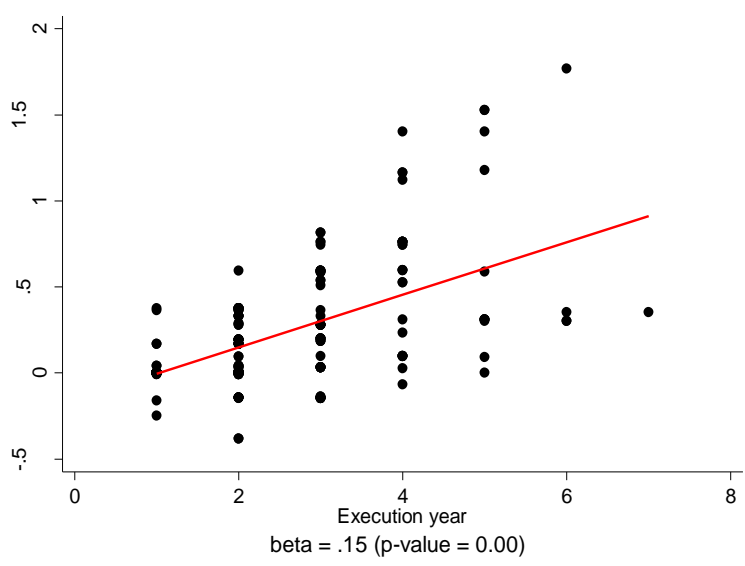

Note: This figure shows the oil price surprise variable over time. Subfigure (a) compares oil price surprise against the year, and (b) against the execution year of the project.

Figure 13. Oil price surprise

Equivalently, figure 14 show the development in gas price surprise both during the sample period and project execution. Unlike the oil price surprise, the gas price surprise appears to significantly trend downwards during the sample period. However, compared to the execution year of the project, there appears to be no significant trend in either direction.

(a) Year

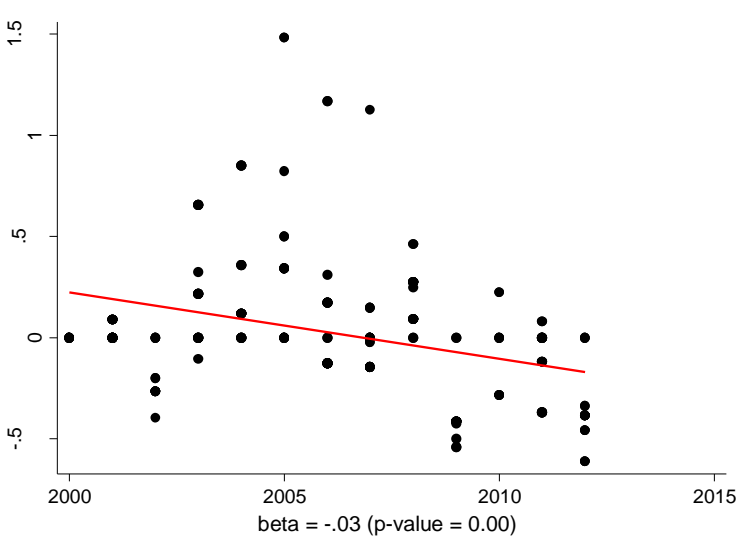

(b) Execution year

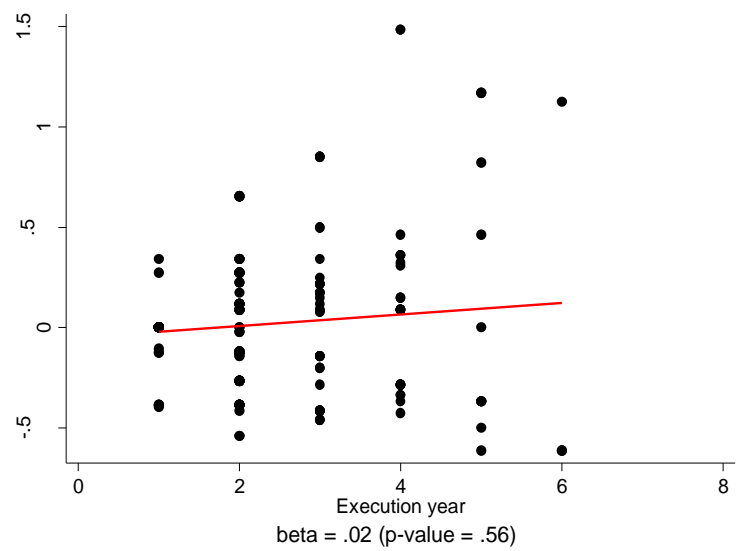

Note: This figure shows the gas price surprise variable over time. Subfigure (a) compare gas price surprise against the year, and (b) against the execution year of the project.

Figure 14. Gas price surprise 
Figure 15 show the development of unexpected change in the number of workers employed in the oil and gas sector - the employment surprise - on the NCS. Both when considering the overall sample period and the execution year, a positive and significant trend is revealed where the latter appears to be stronger.

(a) Year

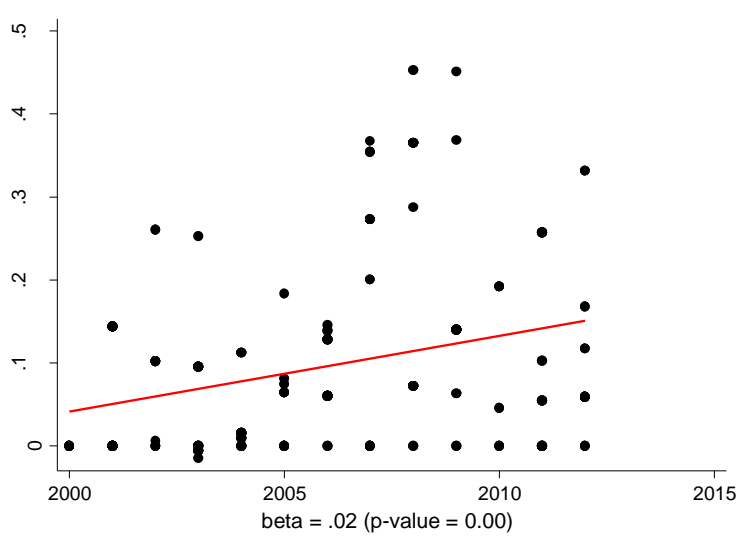

(b) Execution year

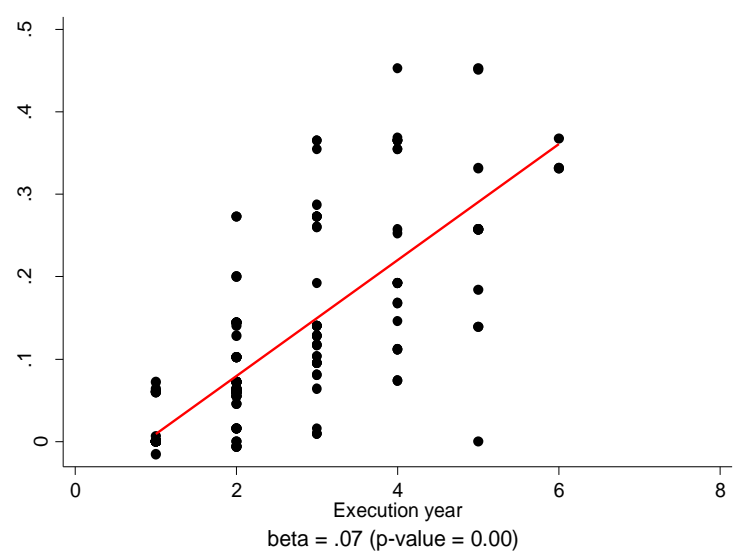

Note: This figure shows the employment surprise variable over time. Subfigure (a) compare employment surprise against the year, and (b) against the execution year of the project.

Figure 15. Employment surprise

Figure 16 show the development of the unexpected change in the aggregate investment on the NCS. Similar to the employment surprise variable, investment surprise exhibits a significant positive trend with the latter being seemingly stronger.

(a) Year

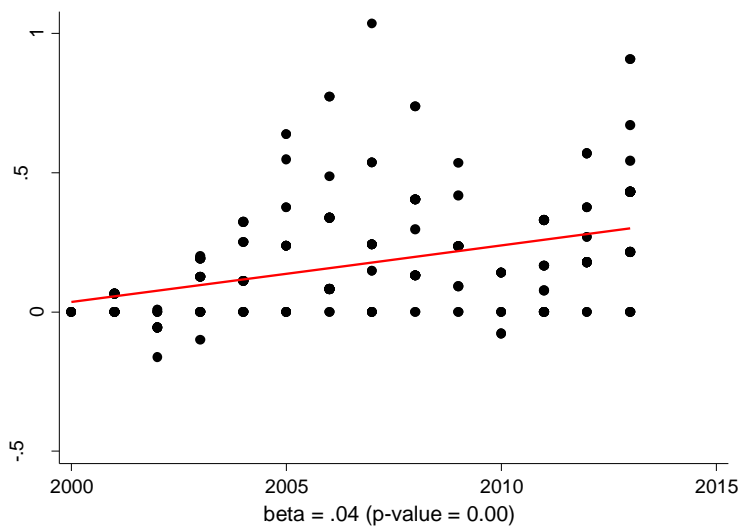

(b) Execution year

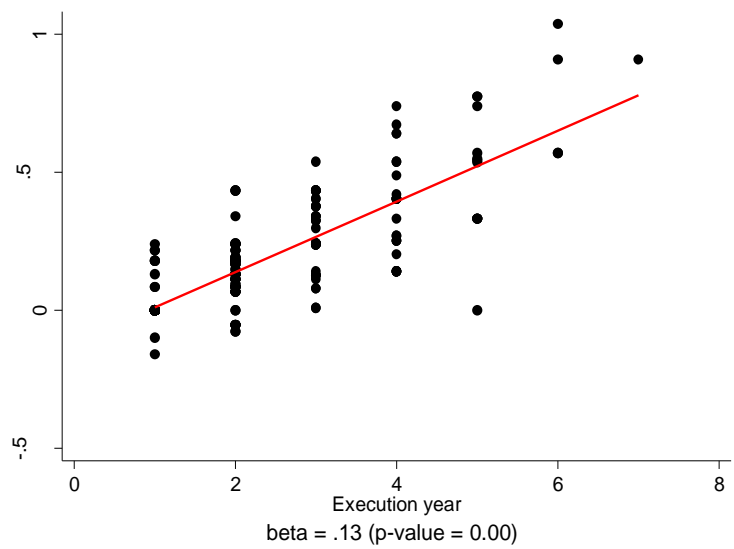


Note: This figure shows the investment surprise variable over time. Subfigure (a) compare investment surprise against the year, and (b) against the execution year of the project.

Figure 16. Investment surprise

Figure 17 shows the development of the unexpected change in the rig rates on the NCS. The rig rate surprise displays a positive and significant trend both over the sample period and across the project execution.

(a) Year

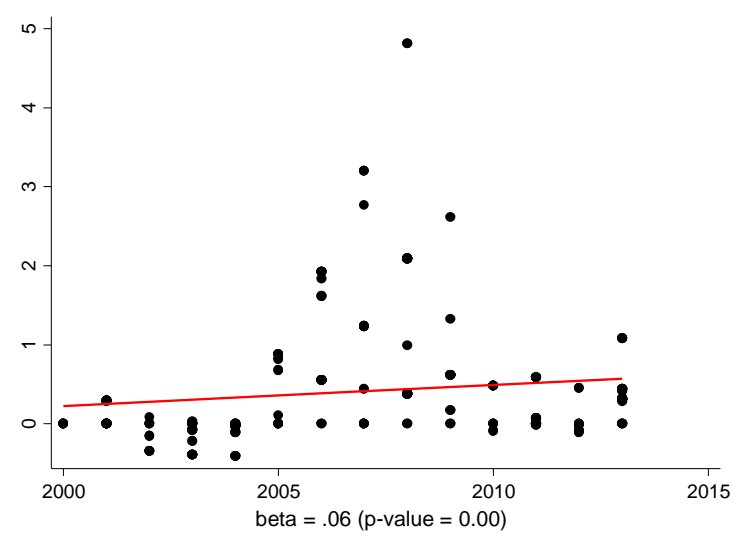

(b) Execution year

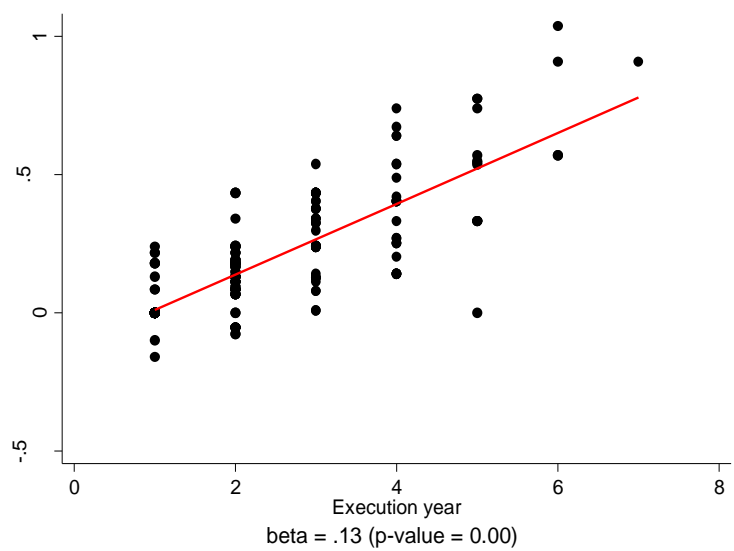

Note: This figure show the rig rate surprise variable over time. Subfigure (a) compare rig rate surprise against the year, and (b) against the execution year of the project.

Figure 17. Rig rate surprise

Figure 18 show development of the unexpected change in wages in the oil and gas industry at the NCS.

(a) Year

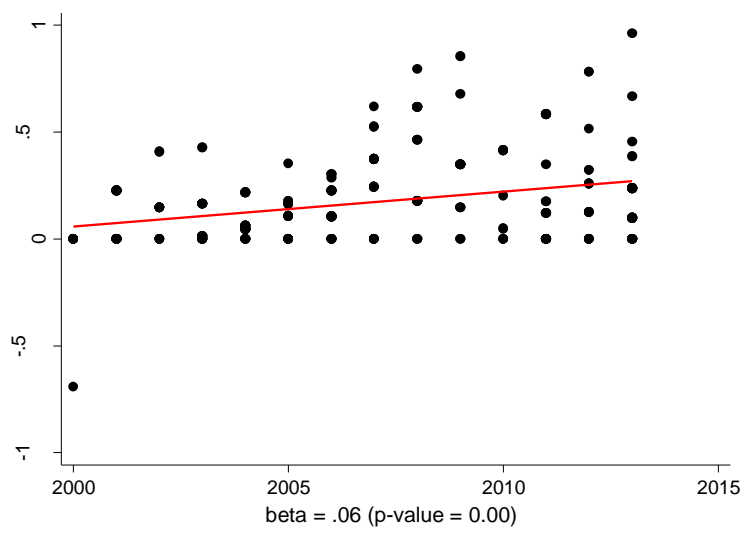

(b) Execution year

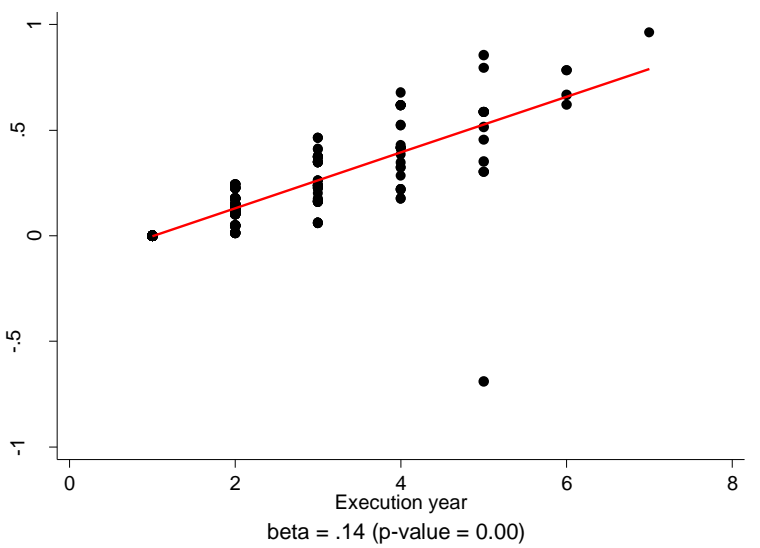


Note: This figure show the wage surprise variable over time. Subfigure (a) compare wage surprise against the year, and (b) against the execution year of the project.

Figure 18. Wage surprise

\section{Regression analysis}

Given the structure of the data, a random effect panel data regression is utilized as the econometric approach to address the research question. To investigate the hypothesized effect of the business cycle we use the relative capex cost overrun of offshore oil and gas projects on the NCS as the dependent variable and various proxies for the economic activity and their respective surprise variable.

Table 5. Univariate cost overrun regression results

\begin{tabular}{llllll}
\hline Variable & Beta & Std. err. & t & p-value & $\mathbf{R}^{2}$ overall \\
\cline { 1 - 3 } & \multicolumn{5}{c}{ Economic activity } \\
Oil Price & 0.004 & 0.001 & 3.36 & 0.00 & 0.05 \\
Gas price & -0.004 & 0.005 & -0.78 & 0.43 & 0.00 \\
Employment & 15.44 & 5.27 & 2.93 & 0.00 & 0.07 \\
Investment & 2.59 & 1.02 & 2.54 & 0.01 & 0.04 \\
Rig rates & 11.09 & 3.65 & 3.04 & 0.00 & 0.05 \\
Wage & 11.19 & 4.17 & 2.68 & 0.01 & 0.05 \\
& \multicolumn{5}{c}{ Surprise variables } \\
Oil price surprise & 0.37 & 0.06 & 6.17 & 0.00 & 0.07 \\
Gas price & -0.13 & 0.18 & -0.70 & 0.48 & 0.01 \\
Employment surprise & 1.79 & 0.37 & 4.79 & 0.00 & 0.29 \\
Investment surprise & 0.91 & 0.20 & 4.58 & 0.00 & 0.24 \\
Rig rate surprise & 0.19 & 0.03 & 6.29 & 0.00 & 0.10 \\
Wage surprise & 1.02 & 0.22 & 4.64 & 0.00 & 0.29 \\
\hline
\end{tabular}

Note: This table shows the regression results for a set of univariate fixed effect panel data regressions. The dependent variable is the relative capex cost overrun for offshore oil and gas projects on the NCS. Standard errors are robust for clustering and heteroscedasticity. The list of evaluated independent variables include annual (monthly average) price of Brent oil (USD/bbl), annual the price (monthly average) of natural gas (USD/Million Btu), the number of employees in the oil and gas sector on the NCS, aggregate investment on the NCS (bn NOK) and average rig rates for floaters on the NCS. Additionally, surprise variables are included for each respective economic activity variable - defined as the relative change from the date of the PDO approval. Employment, Investment and Wage has been scaled by a million for readability.

Based on the descriptive statistics presented in section 4, there is an extensive case of multicollinearity among the variables oil price, rig rates, investments, wages and number of employees. While a set of univariate regression models (see table 5) reveals that the effect of the various economic activity variables on cost overrun are positive and significant, it is not feasible to combine these variables into 
a single multivariate models as the prevalent multicollinearity will render the majority of the variables insignificant. Thus, by utilizing a stepwise forward selection scheme, the variables are sequentially select based on their contribution to the overall explanatory power - conditional on being significant. In addition to the variables subjugated to the univariate regression analysis, we additionally add two project specific control variables - index variable for the project execution time and project size - to the list of variables to be considered for forward selection. Given the prescribed methodology, we arrive at the following specification of the multivariate panel data model for the capex cost overruns:

$$
\begin{aligned}
& \text { CostOverrun }_{i, t} \\
& \qquad \begin{aligned}
& \text { ComployementSurprise }_{i, t}+\beta_{2} \text { ProjectSize }_{i} \\
&+\beta_{3} \text { ExecutionTime }_{i, t}+u_{i}+\varepsilon_{i, t}
\end{aligned}
\end{aligned}
$$

As revealed by table 6, all three variables are statistically significant at a five percentage level. First, the execution year is estimated to have a positive effect on the cost overrun. Based on the obtained beta coefficient, it appears that the capex cost overrun tend to increase by $9 \%$ for each year the project is ongoing. one possible interpretations are that overruns appear late in the projects' lifetime when the co-ordination challenges increase. A supplementary explanation is that initial overruns are underreported in the hope that they can be recouped later on. Project managers tell senior management what they want to hear rather than risk being the bearer of bad news. It can also be argued that, all things equal, this finding indicates that longer projects tend to incur more cost overrun. Second, the employment surprise variable is associated with a positive and significant coefficient of 0.96. This indicates that cost overruns tend to increase by $96 \%$ when the number of employees on the NCS increases with a hundred percent beyond the level of employment at the time of the initiation of project execution. The root cause driving the explanatory power yielded from the employment surprise variable can be challenging to accurately pinpoint. One possibility is that as the number of employees in sector increases, it becomes incrementally more difficult to acquire the necessary amount of skilled labor as the marginal worker typically has lower skills. Moreover, as workers become a bottleneck resource when the business cycle booms and economic activity rises, wages are likely to increase. Less skilled work force reduces productivity below expectations. Scarcity of experienced project managers and controllers in the oil companies reduce the control of the projects. The combined effects is that scarcity of competence leads to cost overruns. Finally, the project size variable exhibits a significant and negative coefficient. As the variable here is defined as the inverse of the ex post cost of the project, it appears that larger projects tend to incur more cost overruns compared to smaller projects. Again, the root cause of the variable's explanatory power is debatable. One possibility is that project size merely represents a crude proxy for complexity, and the presence of complexity is somewhat tautologically making it more difficult to accurately predict project costs. While project size is 
significant, it is the variable with the least amount of contribution to the overall explanatory power. Please note that some previous studies have established a reversed relation between project size and cost overruns, see, e.g. Odeck (2004), Hill et al. (2000), Bertisen and Davis (2008), Creedy (2006) and Cantarelli (2011). The practice in the oil sector of constructing large development projects in several countries, since they go beyond the scope of local input markets, and then fitting them together, with all the challenging timing and potential domino effects it involve, suggests that the risk is increasing in project size in this industry. Thus, summing up, it appears that the signs of the estimated coefficients conforms with ex ante expectations.

Table 6. Multivariate cost overrun regression results

\begin{tabular}{lccccc}
\hline Variable & Coefficient & $\mathbf{t}$ & $\mathbf{p}$-value & Own R $^{\mathbf{2}}$ & ${\text { Cumulative } \mathbf{R}^{\mathbf{2}}}^{\text {Execution year }}$ \\
\hline Employment surprise & 0.09 & 2.14 & 0.03 & 0.3073 & 0.3073 \\
ProjectSize & 0.96 & 2.80 & 0.01 & 0.2938 & 0.3321 \\
\hline & -163.49 & -5.10 & 0.00 & 0.0627 & 0.3759 \\
\hline
\end{tabular}

Note: This table shows the regression result for a multivariate fixed effect panel data regression. The dependent variable is the relative capex cost overrun for offshore oil and gas projects on the NCS. The list of independent variables include the current number of years the projects had been ongoing (execution year), the relative change between the number of employees in the sector at the current year and at the beginning of the project execution (employment surprise), and the inverse of the ex post cost of project in bn NOK (project size). Standard errors are robust for clustering and heteroscedasticity. Own $R^{2}$ is the $R^{2}$ yielded from a univariate regression between cost overrun and the particular variable and cumulative $\mathrm{R}^{2}$ is the explanatory power from a multivariate model including the specific and all preceding variables.

Note that our findings lend support for our two hypotheses. Cost overruns are associated with the business cycle, and the local business cycle parameter employment surprise provides best information on the unexpected cost driving effect of the business cycle.

The overall $\mathrm{R}^{2}$ of the multivariate model is 0.3759 , i.e. almost $38 \%$ of the variability within the data set can be explained by the proposed model. The explanatory power of the model indicates that more research is still required to further reveal the full dynamics of cost overruns. Nevertheless, within the context of this area of research, the achieved $\mathrm{R}^{2}$ is respectable. Given that cost overruns represent the residual unexpected cost incurred during a project execution and not the cost itself, any obtained explanatory power becomes noteworthy. That is, predicating the prevalence and extent of a forecast or estimation inaccuracy is far more challenging than merely predicting the variable itself. To borrow from the classical anecdote of the pool game, it is easy to predict the direction of the pool ball after its first impact and exponentially more difficult on its ninth. To further improve the model it is likely that more project specific variables are necessary. With heterogeneity being one of the defining characteristics of a project, it is difficult to imagine the possibility of explaining the majority of the 
variability within the data without applying project and context specific variables such as operator and owner characteristics, technical complexity in reservoir and design, scope changes, contract forms and factors relating to the suppliers.

(a) Distribution



(b) Residual compared to predicted

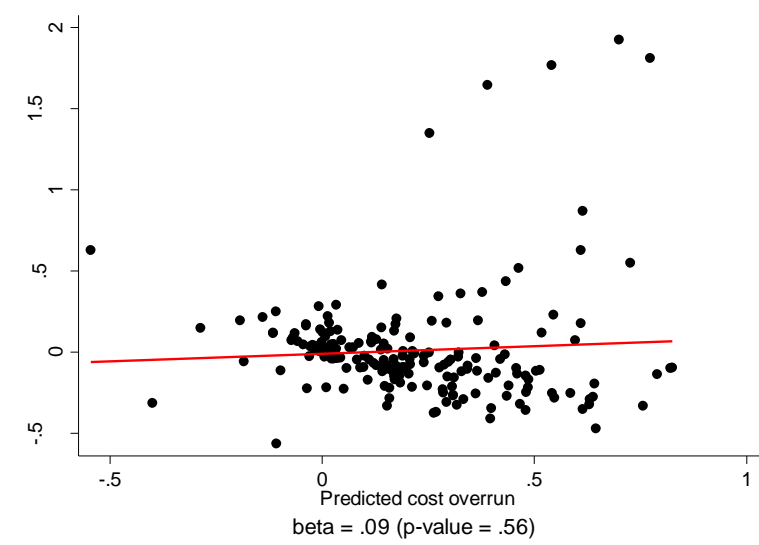

Note: This figure shows the residual from the specified multivariate panel data regression. Subfigure (a) displays the distribution of the residuals with a histogram and an Epanechnikov kernel density plot with the unconditional cost overrun as a reference. Subfigure (b) plots the residual cost overrun against the predicted cost overrun, with a fitted regression line.

Figure 19. Residual analysis

An inspection of the distribution of the residuals of the multivariate model specified in equation 1 reveals that the proposed model is satisfactory on average, see figure 19(a). However, similar to the unconditional cost overrun, the residuals pertain a noteworthy amount of positive skewness. Given that cost overrun by definition is bounded on a scale from -1 (or $-100 \%$ ) to positive infinity, a certain amount of skewness is to be expected. Figure 19(b) tells a similar tale, but additionally it appears that the residual plot exhibits a funnel shape. Thus, is seems that the proposed model is more accurate for projects with lower predicted cost overruns. Consequently, it appears that black swans are more challenging to predict accurately, which is reasonable, as there are fewer opportunities to properly calibrate the predictions. Thus, in conclusion, the proposed model paints a satisfactory picture for the average project, but the presence of positive skewness in the residual distribution and heteroscedasticity in the residual plot indicate that more research is necessary. Therefore, caution should be exercised when attempting to draw inference from the reported result to a specific project. 


\section{Conclusion and policy implications}

We have studied the relationship between cost overruns and business cycle effects. We find that employment surprise, defined as the relative change between the number of employees on the oil and gas sector on the NCS in the current year and at the time of project sanction, has a statistically and economically significant positive effect on cost overruns. This provides support to our hypothesis that the business cycle affects cost overruns as project costs are increasing more in periods of expansion. The labour market provides the best indicator of the business cycle effect. A tight labour market obviously leads to higher wages but also has the effect of reducing productivity as the average competence of the workforce is reduced and as oil companies have insufficient capacity to follow up and control projects. We also find that project size positively affects cost overruns. The same applies to execution year, i.e., cost overruns are more likely to appear in the late stages of a project and longer lasting projects are more prone to have cost overruns.

Policy implications for oil companies are several. Our analysis points to pitfalls in project management. They need to pay special attention to boom periods, and in particular to the recruitment of personnel. They need to recruit before all other companies do the same. This may include a more careful and more selective downsizing of key personnel in times of a low business cycle. Also, special attention must be given large projects and in the mature phase of all projects. They may improve the monitoring of projects so that overruns do not come as a surprise late in the project. The results are also relevant for cost estimation and decision making in oil companies. They need to be particularly aware of cost escalation in booming years. They should pay attention to local business cycle indicators, in particular the labour market. Thus, macroeconomic analysis must play a significant role in cost estimation. This involves tracking the activity of other oil companies closely to get an estimate of the expected overall local activity level.

As for government, our analysis give an additional argument for trying to stabilise the activity on the petroleum sector. It does not only affect employment and macroeconomic indicators but also has an effect on cost overruns and thereby tax revenue. Government may want to stimulate the activity level in years of low activity, so that the industry maintains personnel and competence for years of higher activity. They may pay particular attention to stimulate relevant education in periods of low activity. Curbing high activity is more challenging as it may come at the expense of predictability of the business environment (Osmundsen (2010)). Once licenses are allocated oil companies expect discretion with respect to timing of investments. Tax policy can in principle contribute to evening out the business cycles but once again at the expense of predictability. The decision process, however, is often too slow for this to be effective. The Norwegian Government reduced tax depreciation in 2013 with the 
attention of curbing investments. The timing was unfortunate; the effective tax increase came at the top of the business cycle, thus reinforcing the downturn (Osmundsen et al. (2015)).

We find that the largest cost overruns occur late in project implementation. For project managers this emphasizes the importance of cost control, and suggests that deviations from plan should be dealt with immediately to avoid further cost overruns. In addition, this indicates that projects that have recently been initiated may still experience substantial overruns. Considering the recent drop in oil prices, this is likely to have severe impact on these projects' profitability.

Our results highlight that cost estimates need to be evaluated in the context of the general business climate. We also show that while business cycle effects are relevant for average cost overruns, there is substantial variation between projects not captured by the business cycle proxies.

A common cause of cost overruns is underestimating cost increases directly related to the business cycle. Better estimation of aggregate investment in the petroleum industry would thus improve planning and investment decisions by the companies. It is important to forecast the oil price, but oil companies nevertheless need to strive for consistency in their capital investment planning. Consistency in budgets and investment analysis is crucial for the companies - expected oil and gas prices must be consistent with the expected cost level. We have seen that oil companies in their investment analysis have accounted for increasing oil prices but not fully accounted for the increasing cost that would be the effect of the increase in aggregate investments and employment.

At the same time, it is crucial that macro models are consistent to avoid partial modelling where the effect of a reduction in the oil price is overestimated because the model does not take account of the simultaneous downward pressure on the level of costs such as rig rates and consultant fees. Our research provides input that may alleviate these shortcomings in macro models. At the same time, our analyses of cost overruns highlight crucial factors for cost control.

It is worth noting that the factors contributing to cost overrun are likely to have the opposite effect in the current negative investment climate of falling prices. Idle capacity in the supply industry implies tough competition and lower prices, and probably higher average quality. The oil companies also have more competent personnel to manage projects. Drilling is a prominent example of cost reductions. In times of economic recession, as we now experience, rig rates decrease while drilling productivity increases, which both contribute to decrease drilling $\operatorname{cost}^{5}$. We now see projects with cost underruns, e.g., the giant Sverdrup field at the NCS. This is particularly important at these times when many firms

\footnotetext{
${ }^{5}$ Osmundsen et al. (2010; 2012).
} 
are struggling because of low oil price and little activity. The decreasing drilling cost can now prove continued operation.

Policy implications of the cost overruns may be drawn for oil companies. Oil companies need to be careful to underestimate investment cost in times of boom. Instead, they may attempt to make countercyclical investment, taking advantage of low investment cost in periods of low aggregate activity. To achieve this they need to be financially strong when other companies are weak, by maintaining a high equity share or by being vertically integrated and thus having a revenue stream less affected by the oil price.

To what extent can our results be generalized? Our analysis addresses cost overrun at the level of the Norwegian petroleum industry, thus comprising a large number of licenses, which again each are comprised by typically 3 to 5 companies. The strength of our approach is that the size of the data set allows us to infer general characteristics on deviation between realized and estimated cost. This is of direct interest to the government, as it affects tax payments and aggregate investments and thereby macroeconomic performance. However, it is of no direct relevance to cost estimation in any given particular oil company. To make such an analysis we would need to know the cost estimates of individual companies, which are privileged information. For most companies the data set would at any rate be insufficient to obtain significant results. Individual companies have their own procedures for cost estimation, risk management, project analysis and approval. Thus, one cannot from our analysis infer results from individual firms but from the general cost estimation pattern on the NCS. The cost estimates we analyze are the estimates agreed on in each license. Internally, a company participating in a license may have a different estimate. Our analysis captures the overall picture on the Norwegian shelf. Given the fact that 39 companies are present in our data set, most of them international, and with all supermajors and majors included, and adding the fact that the largest international rig companies and oil service companies are present on the NCS, we believe the results also should be of interest to other petroleum extraction countries. 


\section{References}

Andriosopoulos, Kostas, et al. "Editorial to the special issue "Energy markets and policy implications"." Energy Policy 88 (2016): 558-560.

Bentley, R. and Y. Bentley (2015). "Explaining the price of oil 1971-2014: The need to use reliable data on oil discovery and to account for 'mid-point'peak." Energy Policy 86: 880-890.

Benes, J., Chauvet, M., Kamenik, O., Kumhof, M., Laxton, D., Mursula, S., Selody, J., 2012. The Future of Oil: Geology Versus Technology. IMF Working Paper WP/12/109. International Monetary Fund.

Bertisen, J. and G. A. Davis (2008). Bias and error in mine project capital cost estimation. The Engineering Economist 53 (2), 118-139.

Cantarelli, C. C., B. Flyvbjerg, E. J. Molin, and B. Van Wee (2010). Cost overruns in large-scale transportation infrastructure projects: explanations and their theoretical embeddedness. European Journal of Transport Infrastructure Research 10 (1), 5-18.

Cochrane, John H. "Permanent and transitory components of GNP and stock prices." The Quarterly Journal of Economics (1994): 241-265.

Creedy, G. D. (2006). Risk factors leading to cost overrun in the delivery of highway construction projects.

Emhjellen, K., Emhjellen, M., and P. Osmundsen (2002), "Investment Cost Estimates and Investment Decisions", Energy Policy 30(2), 91-96.

Flyvbjerg, B., Bruzelius, N. and Rothengatter, W. (2003). "Megaprojects and Risk: An Anatomy of Ambition", Cambridge University Press.

Hamilton, J.D. (2009). “Understanding crude oil prices.” The Energy Journal vol. 30, 179-206.

Helm, D. (2002). "Energy Policy: Security of Supply. Sustainability and Competition", Energy Policy, 30, pp. $173-184$.

Hill, J., L. Thomas, and D. Allen (2000). Experts' estimates of task durations in software development projects. International journal of project management 18 (1), 13-21.

Hosseini, S. H. and Shakouri H. (2016). "A study on the future of unconventional oil development under different oil price scenarios: A system dynamics approach." Energy Policy 91: 64-74. 
Maddala, Gangadharrao S., and Shaowen Wu. "A comparative study of unit root tests with panel data and a new simple test." Oxford Bulletin of Economics and statistics 61, no. S1 (1999): 631-652.

Merrow, E. W. (2011). "Industrial Megaprojects: Concepts, Strategies and Practices for Success.", John Wiley \& Sons.

Merrow, E. W. (2012). "Oil and Gas Industry Megaprojects: Our recent track record.", Oil and Gas Facilities vol. 4, $38-42$.

Mishra, N. (2014). "On budget - on time", Conference Speech at The Norwegian Petroleum Directorate.

Mohn, K (2008). "Efforts and Efficiency in Oil Exploration: A Vector Error-Correction Approach", Energy Journal 29, 4, 53-78.

Mohn, K. and P. Osmundsen (2011). "Asymmetry and uncertainty in capital formation: an application to oil investment", Applied Economics, Volume 43, Issue 28, November 2011, 4387-4401.Mohn, K. and P. Osmundsen (2008). "Exploration economics in a regulated petroleum province: The case of the Norwegian continental shelf", Energy Economics 30, 303-320.

Norwegian Petroleum Directorate (2013). "Evaluation of projects implemented on the Norwegian shelf", Norwegian Petroleum Directorate.

NOU (1999). “NOU1999:11 Investeringsutvalget. Analyse av investeringsutviklingen på kontinentalsokkelen. (The investment commission. "Analysis of the investment development on the continental shelf")

Odeck, J. (2004). Cost overruns in road construction - what are their sizes and determinants? Transport policy $11(1), 43-53$.

Osmundsen, P. (2010), "Time Consistency in Petroleum Taxation - Lessons from Norway", in Daniel, P., Keen, M. and C. McPherson, eds., (2010), The Taxation of Petroleum and Minerals: Principles, Problems and Practice, Routledge, joint with the International Monetary Fund.

Osmundsen, P., Roll, K., and R. Tveterås (2010), Exploration Drilling Productivity at the Norwegian Shelf, Journal of Petroleum Science and Engineering, 73, 122-128.

Osmundsen, P., K.H. Roll and R. Tveterås (2012), "Drilling speed - the relevance of experience", Energy Economics 34, 786-794. 
Osmundsen, P., Emhjellen, M., Johnsen, T., Kemp, A. and C. Riis (2015), “Petroleum taxation contingent on counter-factual investment behavior", Energy Journal 36, 1-20.

Osmundsen, P., Skjerpen, T. and K.E. Rosendahl (2015), “Understanding Rig Rate Formation in the Gulf of Mexico", Energy Economics 49, 430-439.

Owen, N., O. Inderwildi, and D. King (2010). "The status of conventional world oil reserves - hype or cause for concern?" Energy Policy, 38, pp. 4743-4749.

Rig Commission (2011), "Økt bore- og brønnaktivitet på norsk sokkel” (Increased drilling and well activity on the Norwegian shelf); expert group appointed by the Norwegian ministry of oil and energy.

Speirs J., C. CMcGlade and R. Slade (2015). "Uncertainty in the availability of natural resources: Fossil fuels, critical metals and biomass." Energy Policy 87: 654-664.

Stirling, A. (2010). "Multicriteria diversity analysis: a novel heuristic framework for appraising energy portfolio." Energy Policy, 38 (4), pp. 1622-1634.

van Moerkerk, M., and W. Crijns-Graus (2016). "A comparison of oil supply risks in EU, US, Japan, China and India under different climate scenarios." Energy Policy 88: 148-158.

Yang Y., J. Li, X. Sun and J. Chen (2014). “Measuring External Oil Supply Risk: A Modified Diversification Index with Country Risk and Potential Oil Exports", Energy, 68, pp. 930-938.

Yergin. D. 2006. Ensuring Energy Security - Old Questions. New Answers. Foreign Affairs. March/April 2006, Vol. 85. no. 2. 


\section{Appendix}

Table 1A. Unit root test for economic activity

\begin{tabular}{|c|c|c|c|c|}
\hline \multirow{2}{*}{ Variable } & \multicolumn{2}{|c|}{ Augmented Dickey-Fuller } & \multicolumn{2}{|c|}{ Phillips-Perron } \\
\hline & without trend & with trend & without trend & with trend \\
\hline Oil price & 0.78 & 0.07 & 0.87 & 0.07 \\
\hline Gas price & 0.72 & 0.22 & 0.80 & 0.23 \\
\hline Rig rates & 0.94 & 0.78 & 0.92 & 0.64 \\
\hline Investment & 1.00 & 0.98 & 1.00 & 0.97 \\
\hline Wages & 1.00 & 0.98 & 1.00 & 0.98 \\
\hline Employees & 0.99 & 0.85 & 0.99 & 0.84 \\
\hline
\end{tabular}

Note: This table shows $p$-values for the unit root test results for the economic activity variables. Augmented Dickey-Fuller and Phillips-Perron test was utilized both with and without a deterministic trend. The null hypothesis under both the ADF and PP test states that a unit root is present in the data.

Table 2A. Panel data unit root test

\begin{tabular}{lllll}
\hline \multicolumn{1}{c}{ Variable } & \multicolumn{2}{c}{ Fisher (Augmented Dickey-Fuller) } & \multicolumn{2}{c}{ Fisher (Phillips-Perron) } \\
& without trend & with trend & without trend & with trend \\
\hline Cost overrun & 0.76 & 1.00 & 0.76 & 1.00 \\
Oil price surprise & 1.00 & 0.88 & 1.00 & 0.88 \\
Gas price surprise & 0.14 & 0.97 & 0.14 & 0.97 \\
Employment surprise & 0.09 & 1.00 & 0.09 & 1.00 \\
Investment surprise & 1.00 & 1.00 & 1.00 & 1.00 \\
Rig rate surprise & 0.98 & 1.00 & 0.98 & 1.00 \\
Wage surprise & 1.00 & 1.00 & 1.00 & 1.00 \\
\hline
\end{tabular}

Note: This table shows $p$-values for the unit root test results for the cost overrun and surprise variables. The Fisher unit root test by Maddala and Wu (1999) with both the augmented Dickey-Fuller and Phillips-Perron specification. The tests were considered both with and without a deterministic trend. The null hypothesis under both the ADF and PP test states that a unit root is present in the data 